\title{
Persoalan Melihat dan Bertemu Rasulullah SAW Secara Yaqazah
}

\author{
Mohammad Amir Wan Harun \\ Universiti Teknologi Malaysia, wanmohammadamir@gmail.com
}

Aminuddin Ruskam

Universiti Teknologi Malaysia, al-dawamy@utm.my

\begin{abstract}
Abstrak
Pertemuan dengan Rasulullah s.a.w. secara yaqazah (jaga) serta melihatnya selepas kewafatan adalah dakwaan yang telah wujud sejak ratusan tahun dahulu sehingga kini. Keharusan perkara ini berlaku diperselisihi dalam kalangan ulama Islam. Justeru, makalah ini membincangkan pandangan serta hujah pihak yang mendakwa keharusan yaqazah berlaku dan pihak yang menolak keharusannya. Kemudian penilaian dilakukan terhadap hujah kedua-dua pihak. Hasil penilaian merumuskan bahawa hujah pihak yang mendakwa keharusan yaqazah adalah tidak kukuh dan tidak memadai bagi mensabitkan kesahihan dakwaannya.
\end{abstract}

Kata kunci: melihat, bertemu, Rasulullah SAW, yaqazah, realiti

\section{The Issue of Seeing and Meeting the Prophet p.b.u.h. Consciously}

\begin{abstract}
Meeting with Rasulullah p.b.u.h. consciously (yaqazah) and seeing him after his death is a claim which has been heard since hundred of years ago until now. This claim has been in conflicts among Islamic Scholars. Hence, this article studies the views and arguments both parties those who claims yaqazah permissibility and who denies it. Afterwards, an evaluation has been made to both arguments. The result shows that the argument from party that claims yaqazah permissibility is not solid and not sufficient enough to certify the validity of the claim.
\end{abstract}

Keywords: meeting, seeing, Rasulullah p.b.u.h., yaqazah, couscious, reality

\section{Pendahuluan}

Dewasa ini memperlihatkan kemeriahan majlis-majlis selawat dan qasidah. Namun begitu, timbul dakwaan kehadiran Rasulullah s.a.w. di sebahagian majlis selawat dan qasidah yang dijalankan. 
Antara yang mendakwa sedemikian adalah Hisyam Kabbani ${ }^{1}$ dan Habib Munzir al-Musawa ${ }^{2}$ di majlis-majlis selawat yang berlangsung di Indonesia. Di sesetengah majlis selawat yang lain, turut diletakkan kerusi kosong di hadapan dan didakwa bahawa Rasulullah s.a.w. akan hadir dan duduk di atas kerusi tersebut. Apabila ditanya kepada Muhadir Haji Joi berkenaan keharusan Rasulullah s.a.w. hadir serta duduk di kerusi kosong tersebut, beliau membenarkannya ${ }^{3}$. Setelah diteliti, dakwaan bertemu Rasulullah s.a.w. secara jaga telah wujud sejak ratusan tahun dahulu. Oleh itu makalah ini membincangkan secara tuntas berkenaan dakwaan ini bagi menjelaskan pandangan serta hujah pihak yang membenarkan keharusan yaqazah berlaku dan pihak yang menolak keharusannya berlaku, seterusnya meneliti setiap hujah serta mentarjihkannya.

\section{Dakwaan Keharusan Melihat dan Bertemu Rasulullah S.A.W. Secara Jaga Selepas Kewafatannya}

Antara individu terawal yang dikaitkan dengan dakwaan bertemu Rasulullah s.a.w. secara jaga adalah Ibn Mandah yang lahir pada tahun $310 \mathrm{Hijrah}^{4}$. Selepas itu, dakwaan ini terus-menerus muncul sehingga ke hari ini. Antara individu yang mendakwa bertemu Rasulullah s.a.w. secara jaga adalah ulama-ulama seperti di bawah.

Pertamanya, Ibn Mandah (310 Hijrah) ${ }^{5}$. Al-Dhahabi telah menukilkan satu kisah dengan sanad terputus dan beliau menyatakan bahawa kisah ini disebut adalah dengan maksud ta'jub (kekaguman) sahaja. Diceritakan pada suatu ketika Ibn Mandah dilihat masuk ke dalam kawasan kubur Rasulullah s.a.w., kemudian setelah beberapa lama beliau pun keluar. Apabila ditanya tujuan perbuatannya itu, beliau menjawab:

"Aku telah merasa ragu-ragu tentang suatu hadis, lalu aku pun datang ke sini dan bertanyakan hadis itu kepada Rasulullah s.a.w., lalu baginda s.a.w. menjawabnya". ${ }^{6}$

1 http://www.youtube.com/watch?v=9SfTX-TCu8Y. Tarikh Akses: 2 Julai 2014.

http://www.youtube.com/watch?v=4mo8nw-skPE. Tarikh akses: 2 Julai 2014.

3 http://www.youtube.com/watch?v=qor8Z1QgfKY. Tarikh akses: 2 Julai 2014.

4 Abū Abdullāh Shams al-Dīn Muhammad bin Aḥmad al-Dhahabi, Siar A'alām al-Nubalā'. (Beirūt: Muassasah al-Risālah, 1985), 37:17.

5 Ibid.

6 Al-Dhahabi, Siar A'alām al-Nubalā', 37:17. 
Keduanya, Aḥmad al-Ghazāli (451 Hijrah). Beliau merupakan saudara kepada Abu Hamid al-Ghazāli. Menurut Ibn Jauzi, terdapat pelbagai ungkapan mungkar daripada perkataan Aḥmad al-Ghazāli. Antara perkataan mungkarnya adalah, beliau mendakwa setiap kali beliau merasa ragu tentang sesuatu, beliau akan bertemu dan melihat Rasulullah s.a.w. secara jaga lalu bertanyakan permasalahan tersebut kepada baginda s.a.w., kemudiannya dijawab oleh baginda s.a.w. ${ }^{7}$. Selain itu beliau turut mendakwa bahawa syaitan telah bersujud kepadanya lebih daripada 70 kali $^{8}$. Ibn Kathīr turut bersetuju dengan dakwaan Ibn Jauzi terhadap Aḥmad al-Ghazāli dan menyebut kisah ini ketika menulis tentang keadaan perilaku Aḥmad al-Ghazāli di dalam kitabnya al-Bidāyah wa al-Nihāyah. ${ }^{9}$

Ketiganya, al-Mardini. Al-Dhahabi menyatakan bahawa dia adalah dajjal penipu yang mendakwa al-Suhbah dan al-Ta'mir pada tahun 599, sedangkan dia mendengar dari Ibn 'Asākir pada sekitar tahun 560. ${ }^{10}$ Menurut Ibn Hajar al-Asqalāni, al-Suhbah yang dimaksudkan oleh al-Dhahabi ke atas al-Mardini merujuk kepada dakwaan bahawa beliau telah melihat Nabi s.a.w. semasa tidur ketika berada di al-Madinah al-Munawwarah, lalu Rasulullah s.a.w. berkata kepadanya: "Kamu telah berjaya di dunia dan akhirat". Kemudian setelah tersedar daripada tidur, beliau mendakwa masih lagi mendengar kata-kata tersebut ${ }^{11}$. Walau bagaimanapun dakwaan al-Mardini ini agak berbeza daripada pengakuan pendakwa yaqazah lain kerana beliau hanya mendakwa mendengar suara Nabi s.a.w. sahaja tanpa melihat baginda s.a.w. secara nyata.

Keempatnya, Abū al-Abbās al-Mursi (615 Hijrah). Beliau merupakan salah seorang pemimpin tarekat al-Shāziliyyah. alManāwi menyatakan bahawa Abū al-Abbās pernah berkata:

7 Abd al-Raḥmān bin Abī al-Ḥasan al-Jauzi, al-Qaṣaṣ wa al-Mudhakkirīn, (Beirūt: al-Maktabah al-Islāmi, 1988), 316.

8 Ibid.

9 Abu al-Fidā' 'Imād al-Dīn Ismā'īl bin 'Umar bin Kathīr, al-Bidāyah wa alNihāyah, (Beirūt: Dār Ihyā’ al-Turāth al-'Arabi, 1988), 243:12.

${ }^{10}$ Abū Abdullāh Shams al-Dīn Muhammad bin Ahmad al-Dhahabi, Mīzan al'Itidāl fi Naqd al-Rijāl, (Beirūt: Dār al-Kutub al-'Ilmiyyah, 1995), 42:2.

${ }^{11}$ Shihāb al-Dīn Ahmad bin 'Ali al-Asqalāni, al-Is̄abah fi Tamyīz al-Saḥābah, (Beirūt: Dār al-Jail, 1991), 519:2. 
"Demi Allah, sekiranya dihijab pandanganku daripada Rasulullah s.a.w. walaupun sekelip mata, nescaya aku tidak lagi mengira diriku termasuk dalam golongan orang Islam". 12

Kelimanya, Ibn Abī Jamrah (695 Hijrah) mendakwa bahawa Rasulullah s.a.w. boleh dilihat serta berbicara dengan manusia secara jaga kerana perkara ini termasuk dalam karāmah waliwali ${ }^{13}$. Menurut Ibn Hajar al-Asqalāni, Ibn Abī Jamrah adalah bertanggungjawab terhadap sebuah riwayat bahawa Ibn Abbās r.a telah bermimpi melihat Rasulullah s.a.w., apabila terjaga beliau sentiasa memikirkan mimpi tersebut. Maka beliau pun masuk bertemu dengan isteri Nabi s.a.w. iaitu ibu saudaranya yang bernama Maimūnah r.a.. Kemudian Maimūnah mengeluarkan cermin milik Rasulullah s.a.w.. Lantas Ibn Abbās r.a. pun melihat ke dalam cermin tersebut, akan tetapi beliau melihat wajah Rasulullah s.a.w. dan tidak melihat wajahnya ${ }^{14}$. Ibn Abī Jamrah juga telah meriwayatkan kisah bahawa sekumpulan orang soleh telah melihat Rasulullah s.a.w. dalam mimpi, kemudian mereka melihatnya secara jaga, lalu mereka bertanya kepada baginda s.a.w. tentang permasalahan yang mereka takuti, lalu baginda s.a.w. menunjuki jalan keluar daripada permasalahan tersebut ${ }^{15}$.

Keenamnya, Jalal al-Din al-Suyuti (849 Hijrah). Di dalam kitabnya "al-Dībāj fì Muslim", al-Suyūti telah mempertahankan kenyataan Ibn Abī Jamhar bahawa melihat Rasulullah s.a.w. secara jaga merupakan salah satu karāmah para wali ${ }^{16}$. al-Sya'rani menukilkan bahawa telah al-Suyūti berkata:

"Aku telah melihat Rasulullah s.a.w. secara jaga dan baginda s.a.w. memanggilku: Wahai syeikh al-hadith. Kemudian aku bertanya: Wahai Rasulullah, adakah aku seorang ahli syurga? Baginda s.a.w. menjawab: Ya. Aku

\footnotetext{
${ }^{12}$ Muḥammad Abd al-Raūf bin Tāj al-'Ārifīn al-Manāwi, Fay ̣̣ al-Qadīr Sharḥ al-Jāmi' al-Ṣaghīr, (Beirūt: Dār al-Kutub al-'Ilmiyyah, 1994), 666.

13 Jalāl al-Din Abd al-Raḥmān bin al-Kamāl al-Suyūti, al-Dībāj 'Alā Saḥịh Muslim, (Saudi Arabia: Dār Ibn Affān, 1996), 285.

${ }^{14}$ Shihāb al-Dīn Ahmad bin 'Ali al-Asqalāni, Fath al-bāri Sharh Ṣaḥ̄h alBukhāri. (Beirūt: Dār al-Ma'rifah, 1960), 385:12.

15 Ibid.

${ }^{16}$ Al-Suyuti, al-Dībāj 'Alā Sahīh Muslim, 285.
} 
bertanya lagi: Tanpa diazab sebelumnya? Rasulullah s.a.w. berkata: Bagimu demikian",17.

Al-Sya'rani turut menukilkan bahawa Sulaimān al-Khudhairi pernah berkata:

"Suatu ketika aku sedang duduk di pintu Imam al-Shāfi'. Tiba-tiba aku melihat satu kumpulan berbaju putih dan berserban daripada cahaya yang datang dari arah bukit. Apabila kumpulan itu telah dekat, aku mendapati mereka adalah Rasulullah s.a.w. dan para sahabatnya. Lalu aku mencium tangan baginda s.a.w. Lalu baginda s.a.w. bersabda: Marilah ikut kami ke al-Raudah. Maka aku telah pergi bersama-sama Nabi s.a.w. sehingga sampai di rumah Syeikh Jalal al-Dīn al-Suyūti. Beliau keluar lalu mencium tangan baginda s.a.w. dan memberi salam kepada para sahabat r.a.. Beliau kemudiannya memasukkan Rasulullah s.a.w. ke dalam rumah dan duduk di hadapannya. Maka alSuyuti mula bertanyakan tentang sebahagian hadis kepada Rasulullah s.a.w., dan baginda s.a.w. berkata: "Nyatakan wahai syeikh al-sunnah ${ }^{18, "}$.

Ketujuhnya, al-Sya'rani (898 Hijrah). Beliau menzahirkan dakwaan keharusan yaqazah dengan menukilkan pelbagai kisah melihat Rasulullah s.a.w. secara jaga. al-Sya'rani telah menulis dalam kitabnya bahawa Abd al-Mawāhib Muḥammad bin Aḥmad al-Shāzili telah berkata:

"Aku telah melihat Rasulullah s.a.w., lalu baginda s.a.w. berkata kepadaku: Sesungguhnya aku tidak mati, sesungguhnya matiku adalah hijab daripada siapa yang tidak kenal Allah S.W.T.. Aku melihatnya dan dia (Rasulullah s.a.w.) melihatku ${ }^{19, "}$.

Al-Sya'rani turut berkata bahawa al-Syāzili sangat kerap melihat Rasulullah s.a.w., dan pernah sekali al-Syāzili berkata:

"Aku mengadu kepada Rasulullah s.a.w. bahawa manusia mendustakanku berkenaan kebolehanku melihatmu, lalu

${ }^{17}$ Abū al-Mawāhib Abd al-Wahhāb bin Aḥmad al-Sya'rāni, al-Ṭabaqāt alSughra@Lawāqih al-Anwār fi Bayān al-'Uhūd al-Muhammadiyyah, (Halab: Dār al-Qalam al-'Arabi, 1993), 30.

${ }^{18} \mathrm{Ibid}, 28-29$.

${ }^{19}$ Abū al-Mawāhib Abd al-Wahhāb bin Aḥmad al-Sya'rāni, al-Ṭabaqāt alKubrā@Lawāqih al-Anwār fì al-Tabaqāt al-Akhyār, (Beirūt: Dār al-Kutub al'Ilmiyyah, 1997), 2:67-70. 
Rasulullah s.a.w. bersabda: 'Demi keagungan Allah s.w.t. dan kebesarannya, barang siapa yang tidak mempercayainya atau mendustakanmu, maka dia tidak mati melainkan sebagai Yahudi, Nasrani atau Majusi", ${ }^{20}$

Kelapannya, Ibn Hajar al-Haithami (909 Hijrah) ketika ditanya kepada beliau adakah mungkin untuk bertemu dengan Nabi s.a.w. secara jaga, jawabnya:

"Ya, dan perkara tersebut merupakan antara karāmah waliwali seperti al-Ghazāli, al-Bārizi, al-Tāj al-Subki, al-'Afífi alYāfi 'i, al-Qurtubi dan Ibn Abī Jamrah ${ }^{21}$ ",.

Beliau juga pernah menukilkan di dalam kitabnya tentang kisah yang diceritakan oleh sebahagian para wali bahawa:

"Seorang wali telah hadir di majlis seorang ulama fekah, lalu alim tersebut telah meriwayatkan sebuah hadis. Lalu wali itu berkata: Hadis ini palsu. Alim itu bertanya: Dari manakah kamu mengetahui ia adalah palsu?. Wali itu menjawab: Ini adalah Nabi s.a.w. berdiri di hadapan kamu dan berkata: Aku tidak pernah mengatakan hadis tersebut. Kemudian disingkap pandangan alim tadi lalu dia juga melihat Nabi s.a.w." 22 .

Kesembilannya, Khujli (1065 Hijrah). Beliau merupakan antara ulama Sudan. Salah seorang anak muridnya iaitu Muḥammad al-Nūr bin Dhaifullāh telah menceritakan bahawa gurunya iaitu Khujli melihat Nabi s.a.w. secara jaga sebanyak 24 kali setiap hari ${ }^{23}$.

Kesepuluh, al-'Ajlūni (1087 Hijrah). Beliau mengakui keharusan bertemu dengan Rasulullah dan bersoal jawab dengan baginda s.a.w. selepas kewafatannya. Ketika menulis mukadimah sebuah kitabnya, beliau dilihat bersetuju dengan pandangan alHatimi al-Tā'i bahawa, sesuatu hadis itu mungkin sahih di sisi para ahli hadis berdasarkan hal perawinya, akan tetapi ia adalah lemah atau palsu di sisi al-Mukāshif (orang yang dapat melihat Rasulullah s.a.w.) berdasarkan pertanyaan mereka kepada

${ }^{20}$ Ibid, 2:67-70.

${ }^{21}$ Shihāb al-Dīn Abū al-Abbās Aḥmad bin Muhammad al-Haithami, al-Fatāwā al-Hadīthiyyah, (Beirūt: Dār al-Fikr, t.thn), 211.

22 Ibid, 211.

${ }^{23}$ Muhammad al-Nūr bin Dhoiffullāh, Tabaqāt Wad Dhoifullāh, (Beirūt: Markaz al-Saff al-Ilektrōni, 2000), 90. 
Rasulullah s.a.w. tentangnya status hadis tersebut. Begitu juga sebaliknya bahawa mungkin sesuatu hadis itu lemah atau palsu di sisi ahli hadis akan tetapi sahih di sisi al-Mukāshif berdasarkan pengkhabaran Rasulullah s.a.w. kepada mereka apabila bertemu ${ }^{24}$.

Kesebelas, al-Zurqāni (1300 Hijrah). Beliau pernah berkata: "Sekiranya seseorang melihat Nabi s.a.w. secara jaga selepas kewafatan baginda s.a.w. dan menyuruhnya sesuatu perkara, maka wajib baginya beramal dengan suruhan itu dan dia tidak termasuk dalam golongan sahabat. Dan wajib juga bagi orang yang membenarkan peristiwa itu untuk beramal dengannya, itulah yang telah diberitahu oleh masyaikh-masyaikh kita ${ }^{25, "}$.

Kedua belas, Muhammad bin "Alawi al-Māliki (1367 Hijrah) di dalam kitabnya "al-dhakhāir al-Muhammadiyyah" berkata: "Roh Mustafa s.a.w. boleh hadir di setiap tempat, ia hadir di tempat-tempat yang baik dan menyaksikan majlis-majlis kebaikan. Dalilnya adalah, hakikat keadaan roh tidak terikat di dalam alam barzakh, bahkan ia bebas di alam ghaib Allah S.W.T.. Manakala roh baginda s.a.w. adalah sesempurna roh, maka ia adalah yang paling sempurna dalam kehadiran dan penyaksian" ${ }^{26}$.

Ketiga belas, al-Habib 'Ali Zainal "Abidin al-Jufri (1391 Hijrah). Apabila beliau ditanya adakah mungkin Nabi s.a.w. hadir ke majlis-majlis zikir? Jawabnya:

"Ya, tetapi bukan seperti mana yang difikirkan oleh orang ramai bahawa Nabi s.a.w. keluar dari kuburnya bersamasama jasad, ia adalah perkataan orang yang tidak berakal. Namun begitu hadirnya roh Nabi s.a.w. adalah mungkin ketika mana kita mendengar tentang sifat-sifatnya dan bentuk rupanya, lalu kita merasakankan kehadirannya di sisi kita ${ }^{27, "}$

${ }^{24}$ Ismā'īl bin Muhammad al-Jarāḥi al-'Ajlūni, Kash al-Khafā' wa Muzīl al-Ilbās 'Ammā Ishtahara min al-Ahāidith 'alā Alsinah al-Nās. (Beirūt: Dār Ihyā' alTurath, 2000), 1:10.

${ }^{25}$ Abu Abdullah Muhammad bin Abd al-Bāqi al-Zurqāni, Sharh al- 'Alāmah alZurqāni 'Alā al-Mawāhib al-Laduniyyah, (Beirūt: Dār al-Kutub al-'Ilmiyyah, 1996), 7:29.

${ }^{26}$ Muḥammad bin 'Alawi al-Māliki, al-Zakhāir al-Muhammadiyyah, (AlQāherah: Dār al-Jawāmi’ al-Kalām, 1995), 309-310.

${ }^{27}$ Al-Habīb 'Ali Zainal 'Ābidīn al-Jufri. Rakaman wawancara: http://www.you tube.com/watch?v=mGxy68rfp6E. Tarikh akses: 5 Jun 2014. 
Dalam ketika yang lain, beliau turut bersetuju dengan pandangan al-Sya'rani berkenaan hal melihat Nabi s.a.w. secara jaga. Perkara ini dapat dipastikan apabila beliau sering menukilkan kata-kata dan pandangan al-Sya'rani berkenaan perkara ini dalam ceramah-ceramah beliau ${ }^{28}$.

Keempat belas, 'Ali al-Jum'ah (1364 Hijrah). Beliau merupakan bekas Mufti Mesir. Beliau pernah ditanya adakah mungkin melihat Nabi s.a.w. secara jaga? Jawabnya: "Ya mungkin, dan aku sendiri pernah melihat Nabi s.a.w. secara jaga ${ }^{29, "}$.

Sebahagian dari mereka mengakui secara jelas keharusan melihat dan bertemu Nabi s.a.w. secara jaga, manakala sebahagian lagi dilihat bersetuju dengan dakwaan ini walaupun tidak menyebutnya secara jelas.

\section{Perbezaan Kaedah Melihat dan Bertemu Rasulullah S.A.W. Secara Jaga}

Terdapat perbezaan berkenaan kaedah melihat Rasulullah s.a.w. secara jaga di sisi mereka yang mendakwa keharusan perkara ini berlaku. Sebahagian orang soleh mengatakan bahawa melihat Rasulullah s.a.w. adalah dengan mata zahir $^{30}$. Ahli hadis pula mendakwa ia adalah dengan pandangan mata hati ${ }^{31}$. al-Suyūti pula menyatakan, pengalaman paling banyak yang pernah dialami oleh manusia dalam melihat Rasulullah s.a.w. secara jaga adalah melihat dengan hati, kemudian meningkat kepada melihat dengan pandangan. Namun begitu, pandangan tersebut bukanlah seperti yang diketahui oleh manusia seperti mana mereka melihat sesama mereka, tetapi ia adalah pandangan dalam keadaan barzah dan urusan kejiwaan yang tidak mengetahui hakikatnya melainkan orang yang pernah merasainya sahaja. Berbeza dengan 'Ali Zainal 'Abidin al-Jufri, beliau berpandangan bahawa adalah mustahil melihat Rasulullah s.a.w. dengan mata zahir manusia, akan tetapi

${ }^{28}$ Al-Habib Ali Zainal 'Ābidin al-Jufri. Rakaman wawancara: www.youtube .com/watch?v=VvSS3Xct_pQ. Tarikh akses: 5 Jun 2014.

${ }^{29}$ Ali al-Jum'ah. Rakaman wawancara: http://www.youtube.com/watch? $\mathrm{v}=\mathrm{rg} 610$ HvsQUs. Tarikh akses: 5 Jun 2014.

${ }^{30}$ Ibn Ḥajar al-Asqalāni, Fath al-Bāri Sharh Ṣahịh al-Bukhāri, 12:384 ; Ali alJum'ah. Rakaman wawancara: http://www.youtube.com/watch? $\mathrm{v}=\mathrm{rg} 610 \mathrm{Hvs}$ QUs. Tarikh akses: 5 Jun 2014.

${ }^{31}$ Ibn Hajar al-Asqalāni, Fath al-Bāri Sharh Șahih al-Bukhāri, 12:384. 
penglihatan itu hanyalah perasaan jiwa akan kehadiran roh Rasulullah s.a.w ${ }^{32}$.

\section{Perbezaan Keadaan Rasulullah S.A.W. Hadir di Sisi Pihak yang Mendakwa Melihatnya Secara Jaga}

Pihak yang mendakwa melihat Rasululllah s.a.w. secara juga berselisih pendapat berkenaan keadaan Rasulullah s.a.w. hadir di sisi mereka. Sebahagian dari mereka mendakwa bahawa kehadiran Rasulullah s.a.w. adalah dengan jasad beserta roh, sebahagian lagi mendakwa hanya roh baginda s.a.w. sahaja yang hadir, manakala pandangan lain mengatakan kehadiran tersebut hanyalah gambaran atau bayangan Nabi s.a.w. sahaja.

Menurut al-Qādhi Abū Bakar bin al-'Arabi, adalah harus melihat zat jasad beserta roh Nabi s.a.w. kerana baginda s.a.w. dan seluruh para Nabi a.s. adalah hidup. Roh mereka dikembalikan selepas kematian mereka, mereka dibenarkan keluar dari kubur dan bergerak bebas di alam ghaib langit dan bumi, tiada halangan ramai manusia melihat Rasulullah s.a.w. dalam masa yang sama kerana baginda s.a.w. seumpama matahari yang boleh dilihat oleh semua manusia dalam masa yang sama ${ }^{33}$.

Menurut pandangan Ibn Hajar al-Haithami pula, melihat Rasulullah s.a.w. dengan sifat baginda s.a.w. yang diketahui adalah melihat hakikat zat baginda s.a.w., atau terbuka hijab lalu dapat melihat jasad Rasulullah s.a.w. di dalam kubur. Namun begitu, kebanyakan penglihatan yang berlaku kepada manusia adalah gambaran baginda s.a.w. sahaja ${ }^{34}$. al-Ghazāli pula berpandangan, melihat Rasulullah s.a.w. bukanlah melihat jasad dan roh baginda s.a.w., tetapi ia adalah gambaran baginda s.a.w. sahaja. Hal ini seperti orang yang bermimpi melihat Allah s.w.t., bukanlah dia melihat zat Allah, tetapi dia hanya melihat gambaran sifat Allah s.w.t. sahaja ${ }^{35}$. Manakala Muhammad bin 'Alawi alMāliki menyatakan bahawa hanya roh Nabi s.a.w. sahaja yang hadir $^{36}$. Pandangan ini disokong oleh al-Habib 'Ali Zainal 'Abidin

\footnotetext{
${ }^{32}$ Al-Habib Ali Zainal 'Abidin al-Jufri, www.youtube.com/watch?v=VvSS3Xct _pQ, Tarikh akses: 5 Jun 2014.

33 Ibn Hajar al-Haithami, al-Fatāwā al-Hadithiyyah, 1:704.

${ }^{34}$ Ibid.

35 Jalāl al-Din Abd al-Raḥmān bin al-Kamāl al-Suyūti, al-Hāawi li al-Fatāwā, (Beirūt: Dār al-Kutub al-Qurāniyyah, 2000), 2:249.

${ }^{36}$ Muḥammad bin 'Alawi al-Maliki, al-Zakhāir al-Muhammadiyyah, 309-310.
} 
al-Jufri dengan menegaskan bahawa melihat zat jasad Rasulullah s.a.w. adalah dakwaan orang yang tidak berakal, tetapi yang hadir dan dapat dirasai itu adalah roh baginda Rasulullah s.a.w. sahaja ${ }^{37}$.

\section{Hujah Serta Dalil Dakwaan Keharusan Melihat dan Bertemu Rasulullah S.A.W. Secara Jaga}

Pihak yang mendakwa keharusan melihat Rasulullah s.a.w. secara jaga menyandarkan dakwaan mereka kepada beberapa hujah serta dalil 'aqli dan naqli seperti berikut.

Pertamanya, hadis daripada Abū Hurairah r.a. bahawa Rasulullah s.a.w. bersabda:

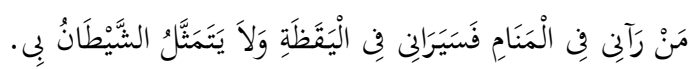

"Barang siapa melihatku dalam mimpi, maka dia akan melihatku dalam jaga, dan syaitan tidak akan dapat menyerupaiku ${ }^{38, "}$

Hadis ini menurut al-Qādhi Abū Bakar al-“Ārabi memberi maksud yang jelas dan zahir bahawa orang yang bermimpi melihat Nabi s.a.w., maka dia akan berpeluang selepas itu melihat Nabi s.a.w. secara jaga dengan kedua matanya sendiri, dan dikatakan juga akan melihat dengan mata hatinya ${ }^{39}$. al-Suyūti juga dilihat bersetuju dengan tafsiran al-Qādhi ini kerana beliau sering menukilkan serta mempertahankan tafsiran al-Qādhi ini di dalam karya-karya beliau $^{40}$.

Keduanya, Nabi Muhammad s.a.w. dan seluruh para Nabi a.s. adalah hidup, roh mereka dikembalikan ke dalam jasad setelah mereka meninggal dunia. Maka jasad yang hidup adalah boleh dilihat oleh manusia yang hidup. Dakwaan ini bersandarkan kepada beberapa hujah seperti berikut:

a. Hadis daripada Anas bin Malik r.a. bahawa Nabi s.a.w. bersabda:

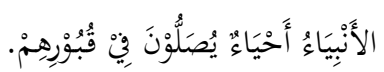

37 'Ali Zainal Abidin al-Jufri, www.youtube.com/watch?v=VvSS3Xct_pQ, Tarikh akses: 5 Jun 2014.

38 Al-Bukhari, al-Jāmi' al-Șahīh. (Beirūt: Dār Tūq al-Najāh, 2002). No 6933

39 Al-Suyūti, al-Hāwi li al-Fatāwāa, 2:242.

${ }^{40}$ Al-Suyūti, al-Dī̄ajaj 'Alā Șahịh Muslim, 5:285; al-Suyūti, al-Hāwi li alFatāwā, 2:242. 
"Para Nabi a.s. adalah hidup dan bersolat di dalam kubur mereka ${ }^{4 l}$,

b. Sesungguhnya Rasulullah s.a.w. ketika hidup pernah melihat dan bertemu dengan para Nabi a.s. yang telah wafat, seperti peristiwa Rasulullah s.a.w. melihat Nabi Isa a.s. bertawaf di Kaabah dan peristiwa Rasulullah s.a.w. melihat Nabi Musa bersolat di dalam kuburnya. Bahkan menurut al-Suyūti, di akhir zaman nanti Nabi 'İsa a.s. akan turun lalu pergi berjumpa dengan Nabi Muhammad s.a.w. untuk mempelajari syariat Islam ${ }^{42}$.

Ketiganya, perkara luar biasa yang boleh berlaku kepada para Nabi a.s. sebagai mukjizat boleh juga berlaku kepada para wali sebagai karāmah dengan syarat tiada al-țahaddi (cabaran kepada pihak lain untuk mengatasi sesuatu kelebihan). Hujah ini dinyatakan oleh al-Yāfi'e dan dinukilkan oleh Ibn Ḥajar alHaithami dalam kitabnya ${ }^{43}$.

\section{Penolakan Dakwaan Keharusan Melihat dan Bertemu Rasulullah S.A.W. Secara Jaga}

Sesungguhnya mimpi bertemu Rasulullah s.a.w adalah suatu nikmat yang didambakan oleh setiap Muslim dan keharusan bermimpi Rasulullah s.a.w. adalah tidak dipertikai. Namun begitu terdapat sebahagian dakwaan yang mengakui keharusan bertemu Rasulullah s.a.w. secara jaga selepas kewafatannya. Kesahihan dakwaan telah diperbahaskan oleh para ulama dan sebahagiannya telah menolak dakwaan keharusan melihat Rasulullah s.aw. secara jaga. Antaranya adalah ulama-ulama berikut.

Pertamanya, al-Qurtubi (578 Hijrah). Beliau merupakan guru kepada pengarang Tafsīr al-Qurtubi iaitu Abū Abdullah alQurtubi. Beliau menolak tafsiran secara zahir berkenaan hadis Abū Hurairah r.a. ${ }^{44}$ yang dipegang oleh pihak yang mendakwa keharusan Rasulullah s.a.w. secara jaga dengan berkata:

\footnotetext{
${ }^{41}$ Al-Bazzār, Musnad al-Bazzār. (Al-Madīnah al-Munawwarah: Maktabah al'Ulūm wa al-Hikam, 2009). No 6888, - Sanad sahih menurut al-Albāni.

42 Jalāl al-Dīn Abd al-Raḥmān bin al-Kamāl al-Suyūti, Nuzūl 'T̄sā bin Maryam fì Ākhir al-Zamān, (Iskandariah: Dār Ibn Khaldūn, t.thn), 21 ; Ibn Hajar alHaithami, al-Fatāwā al-Hadithiyyah, 1:704.

${ }^{43}$ Ibn Hajar al-Haithami, al-Fatāwā al-Hadithiyyah, 1:704.

${ }^{44}$ Dari Abu Hurairah r.a., Rasulullah s.a.w. bersabda: "Barang siapa melihatku di dalam mimpinya, maka dia akan melihatku secara jaga". Hadis riwayat alBukhari: 6933.
} 
"Tafsiran ini adalah perkataan orang yang rosak akalnya kerana tafsiran tersebut memberi maksud bahawa seseorang itu melihat Nabi s.a.w. dalam kondisi tubuhnya ketika wafat, tidak mungkin dua orang melihatnya dalam satu masa dan tidak mungkin dilihat dalam dua tempat pada satu masa, dan baginda s.a.w. adalah hidup ketika ini, keluar dari kuburnya dan berjalan di pasar-pasar, berbicara dengan manusia dan manusia berbicara dengannya. Tafsiran ini juga memberi erti bahawa kuburnya kosong dari tubuh baginda s.a.w., maka yang diziarahi oleh manusia hanyalah kubur semata-mata dan manusia hanya memberi salam kepada sesuatu yang tiada kerana menurut mereka baginda s.a.w. harus dilihat secara hakikat pada waktu malam atau siang yang terikat dengan waktu-waktu di tempat selain kuburnya. Tafsiran ini adalah kejahilan yang tidak seharusnya datang daripada orang yang berakal ${ }^{45}$.

Keduanya, Ibn Taymiyyah (661 Hijrah). Beliau telah berkata: "Syaitan sering mendatangi manusia semasa tidur atau berjaga. Kadang kala manusia didatangi oleh syaitan dalam bentuk yang tidak dikenalinya lalu berkata: 'Aku syeikh fulan, alim fulan'. Mungkin juga ia berkata: 'Aku Abu Bakar, Umar'. Mungkin juga ia berkata: 'Aku Musa al-Masih, Aku Muhammad'. Perkara ini aku ketahui banyak berlaku kepada manusia'. Dan di antara mereka ada yang menyangka bahawa ketika mereka pergi ke kubur Nabi s.a.w., lalu baginda s.a.w. keluar dari kuburnya dalam bentuk tubuh baginda s.a.w. dan berkata-kata dengan mereka...dan mereka menjadikan perkara ini sebahagian dari karāmah para wali. ${ }^{46}$.

Ibn Taymiyyah telah menukilkan perkataan Ibn Abd al-Bā bahawa beliau berkata kepada orang yang mendakwa melihat Nabi s.a.w. secara jaga:

"Celaka kamu! Adakah kamu merasakan diri kamu lebih baik daripada orang yang terdahulu dari kalangan sahabat

${ }^{45}$ Abū al-Abbās Aḥmad bin 'Umar al-Ansāri al-Qurtubi, al-Mufahhim Limā Ushkila min Talkhīs Kitāb Muslim, (Beirūt: Dār Ibn Kathīr, 1996), 18:128.

${ }^{46}$ Ibn Taimiyyah Taqiyuddīn Aḥmad bin Abd al-Halīm, Risālah al-'Ibadāt alSyar'iyyah wa al-Farq Bainahā wa Baina al-Bid 'ah. (Al-Ihsā': Maktabah Ibn al-Jauziyyah, t.thn), 36 . 
Muhajirin dan Ansor? Adakah dikalangan mereka terdapat orang yang bertanya kepada Nabi s.a.w. selepas kewafatannya lalu pertanyaan mereka dijawab? Sesungguhnya telah berlaku banyak perselisihan di kalangan para sahabat, mengapa mereka tidak bertanya kepada Rasulullah s.a.w. agar perselisihan mereka dijawab oleh baginda s.a.w.? Anak baginda s.a.w. Fatimah r.a. telah berselisih pandangan tentang harta warisannya, mengapa beliau tidak bertanya terus kepada Rasulullah s.a.w. ${ }^{47}$ ?"

Ketiganya, Ibn Hajar al-'Asqalāni (773 Hijrah). Beliau berkata:

"Perkara ini (melihat Rasulullah s.a.w. secara jaga) adalah sangat meragukan. Jika dikira dari segi zahirnya maka mereka yang melihat itu adalah dikira sebagai golongan sahabat r.a., dan golongan sahabat akan wujud berkekalan sehingga hari kiamat. Dan yang lebih meragukan, ramai manusia yang bermimpi melihat Rasulullah s.a.w. tetapi mereka tidak pula menyebut bahawa mereka dapat melihat Rasulullah s.a.w. secara jaga, dan pengkhabaran yang benar itu tidak saling bercanggahan ${ }^{48, "}$.

Keempatnya, al-Sakhāwi (831 Hijrah). Beliau berkata: "Tidak pernah sampai kepada kami berkenaan dakwaan melihat Rasulullah s.a.w. secara jaga oleh salah seorang daripada Sahabat Rasulullah s.a.w., atau pun orang selepas mereka (dari kalangan Tabiin dan tabi' Tabiin). Sesungguhnya Fatimah r.a. telah dilanda kesedihan yang bersangatan hingga membawa kepada kematiannya selepas enam bulan kewafatan Rasulullah s.a.w. sedangkan rumahnya adalah bersebelahan dengan kubur baginda s.a.w.. Walaupun begitu, tidak didengari bahawa beliau melihat Rasulullah s.a.w. secara jaga dalam tempoh berbaki hayatnya $^{49, " .}$

Kelimanya, al-San‘āni (1099 Hijrah). Setelah beliau membahaskan di dalam kitabnya bahawa adalah tidak mungkin

\footnotetext{
${ }^{47} \mathrm{Ibid}, 37$.

${ }^{48}$ Ibn Hajar al-Asqalāni, Fatḥ al-Bāri Sharh Ṣaḥ̄ḥ al-Bukhāri, 12:385.

${ }^{49}$ Shihāb al-Dīn Aḥmad bin Muhammad al-Qastalāni, al-Mawāhib alLaduniyyah, (Dimasyq: al-Maktab al-Islāmi, 2004), 2/295.
} 
orang yang telah meninggal dunia kembali berhubung dengan orang yang masih hidup, beliau berkata:

"Sekiranya dakwaan ini tidak datang daripada orang yang tidak berakal, maka tiadalah orang yang tidak berakal dalam dunia ini. Dan yang lebih aku hairan adalah perkataan alSuyūti (sesungguhnya di antara karāmah wali adalah melihat Rasulullah s.a.w. dan bertemu dengannya secara jaga, serta mengambil daripadanya sebahagian ilmu dan pengetahuan....) Sesungguhnya dakwaan-dakwaan ini tidak seharusnya datang daripada orang yang berakal, khususnya orang yang mengetahui tentang ilmu akal dan naqal. Telah sabit bahawa para sahabat r.a. sangat ingin bertanyakan kepada Rasulullah s.a.w. selepas kewafatannya tentang ilmu agama tetapi mereka tidak memperolehinya. Maka bagaimana ijtihad itu dibenarkan dalam Islam sekiranya Rasulullah s.a.w. masih dapat berhubung dengan manusia bagi memberi jawapan dalam setiap permasalahan ${ }^{50}$ ?".

Keenamnya, al-Laknawi (1264 Hijrah). Ketika beliau membahaskan di dalam kitabnya tentang dakwaan kehadiran Nabi s.a.w. di majlis-majlis peringatan hari kelahirannya, beliau berkata: "Perkara ini termasuk dalam kebatilan-kebatilan yang tiada satu dalil pun mengesahkannya, ia hanyalah kemungkinan yang keluar dari garis kebenaran ${ }^{51}$ ".

Ketujuhnya, Ibn Bāz (1327 Hijrah). Beliau telah berkata:

"Sebahagian manusia menyangka Nabi s.a.w. hadir ke majlis mawlid, oleh itu mereka bangun meraikan bagi menyambut kedatangannya. Sangkaan ini adalah sebesar-besar kebatilan dan seburuk-buruk kejahilan. Sesungguhnya Rasulullah s.a.w. tidak keluar dari kuburnya sebelum hari kiamat, baginda s.a.w. tidak berhubung dengan sesiapa di kalangan manusia, tidak menghadiri perhimpunan mereka, bahkan baginda s.a.w. mendiami di dalam kuburnya sehingga ke hari kiamat dan rohnya berada di tempat tertinggi di sisi Tuhannya. Hal ini seperti mana firman Allah S.W.T

${ }^{50}$ Muhammad bin Ismā‘̄il al-San'āni, al-Insāf fi Haqīqah al-Auliyā' wamā Lahum min al-Karāmāt wa al-Altāe. (Al-Qāherah: Dār Ibn Affān, 1997), 2123.

${ }^{51}$ Abd al-Haȳ Abd al-Halīm al-Laknawi, al-Athār al-Marfū'ah fì al-Akhbār alMaudhū'ah. (Beirūt: Dār al-Kutub al-'Ilmiyyah, t.thn), 46. 
(Kemudian kamu selepas ini akan dimatikan, kemudian kamu selepas itu akan dibangkitkan) [Surah al-Mukminun, 23: 1516]. Sabda Nabi s.a.w.: (Aku adalah yang pertama dikeluarkan dari kubur pada hari kiamat). Kedua-dua dalil menunjukkan bahawa Rasulullah s.a.w. serta manusia lain tidak akan keluar dari kubur melainkan pada hari kiamat, perkara ini telah dipersepakati di kalangan ulama Islam".

Kelapannya, Muḥammad Aḥmad Lūh (1374 Hijrah). Beliau telah berkata:

"Sesungguhnya kepercayaan ini (melihat Rasulullah s.a.w. secara jaga) bercanggah dengan persepakatan Ahli Sunnah Wal Jamaah, ia adalah kepercayaan khusus ahli bidaah. Beliau menukilkan perkataan Ibn Hazam bahawa, para ulama telah bersepakat bahawa Muhammad s.a.w. dan seluruh para sahabatnya tidak kembali ke dunia sehinggalah hari kebangkitan seluruh manusia) $)^{52}$.

Pandangan-pandangan yang diutarakan ini menzahirkan secara jelas penolakan sebahagian ulama terhadap dakwaan melihat Rasulullah s.a.w. secara jaga. Bahkan sebahagiannya secara keras mengatakan ia merupakan perkara batil yang jauh daripada kebenaran dan kesepakatan Ahli Sunnah wa al-Jamaah.

\section{Hujah serta Dalil Menolak Keharusan Melihat dan Bertemu Rasulullah S.A.W. Secara Jaga}

Pihak yang menolak keharusan melihat dan bertemu Rasulullah s.a.w. secara jaga menyandarkan pendirian mereka kepada hujah serta dalil berikut.

Pertamanya, dakwaan ini menyalahi ajaran al-Quran seperti yang difirmankan oleh Allah S.W.T:

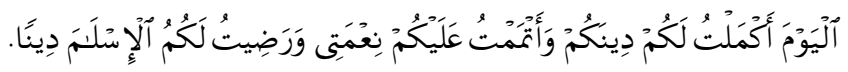

"Pada hari ini aku telah sempurnakan bagi kamu agama kamu dan aku telah lengkapkan ke atas kamu nikmatku dan aku redha Islam sebagai agama kamu”.

Surah al-Māidah 4:3

Menurut Muḥammad Aḥmad Lūh, sekiranya dakwaan melihat, bertemu dan bersoal jawab dengan Nabi s.a.w adalah

\footnotetext{
${ }^{52}$ Muḥammad Aḥmad Lūh, Taqdīs al-Ashkhās fi al-Fikr al-Sūfi, (Al-Qāherah: Dār Ibn 'Affān, 2002), 45.
} 
benar, maka ia akan membawa kepada berterusannya pensyariatan Islam, sedangkan di dalam al-Quran, Allah S.W.T menyatakan bahawa Islam itu telah lengkap pada akhir hayat Nabi s.a.w., manakala kewafatan Nabi s.a.w. merupakan titik berakhirnya wahyu sama ada daripada al-Quran mahupun hadis. Maka sekiranya benar dakwaan ini, setiap apa yang diucapkan oleh Nabi s.a.w. ketika kehadirannya merupakan wahyu dan pensyariatan. Perbuatan ini adalah mengingkari firman Allah S.W.T. dalam alQuran dan adalah mustahil perkara ini berlaku ${ }^{53}$.

Keduanya, dakwaan ini bercanggah dengan hadis sahih daripada Abū Hurairah r.a:

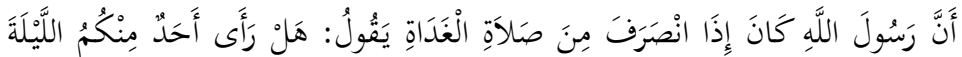

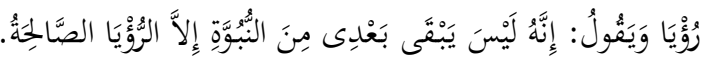

"Bahawa apabila Nabi s.a.w. telah selesai solat subuh, baginda s.a.w. akan bertanya: Adakah sesiapa di kalangan kamu yang bermimpi semalam? Kemudian baginda s.a.w. berkata: Sesungguhnya tiada perkara kenabian berlaku selepasku melainkan mimpi yang baik" ${ }^{\text {"54 }}$.

Abd al-Muhsīn al-'Ibād ketika mensyarahkan hadis ini berkata, bukanlah ia bermaksud bahawa kenabian itu masih wujud pada masa kini kerana kenabian adalah khusus kepada para Nabi a.s dan ia berakhir dengan kewafatan Rasulullah s.a.w.. Dimaksud perkara kenabian adalah perkara ghaib yang diketahui oleh Nabi s.a.w. melalui wahyu, dan ia juga boleh diketahui melalui mimpi yang baik ${ }^{55}$. Dalam hadis ini Nabi s.a.w. memberitahu bahawa selepas kewafatannya, tiada maklumat berkenaan perkara ghaib dapat disampaikan melainkan melalui mimpi sahaja. Sekiranya benar dakwaan bahawa Nabi s.a.w. hadir pada masa kini lalu mengkhabarkan tentang sebahagian perkara ghaib, ia adalah perbuatan yang menyalahi hadis Nabi s.a.w. itu sendiri. Adalah mustahil perkara tersebut ke atas Nabi s.a.w..

53 Ibid, 46.

${ }^{54}$ Abū Dāūd, Sunan Abī Dāūd, (Riyādh: Maktabah al-Ma'ārif li al-Nashar wa alTauzi', 2003), 4:462, No hadis: 5019 ; Ahmad bin Hanbal, Musnad Ahmad bin Hanbal. (Beirūt: Muassasah al-Risālah, 2001), 2:325, No hadis: 8296 ; Sanad hadis sahih menurut Shuaib al-Arnawūt.

${ }^{55}$ Abd al-Muhsin al-'Ibād, Sharh Sunan Abì Dāūd, Islamweb.net, t.thn, (Kaset Rakaman no. 481-598), http://audio.islamweb.net/audio/index.php?page=lecview $\&$ sid $=317 \&$ read $=0 \& \lg =338$. 
Ketiganya, dakwaan ini tidak pernah wujud di zaman hidupnya manusia-manusia terbaik selepas Rasulullah s.a.w. iaitu zaman sahabat r.a., zaman tabiin dan tabi tabiin.. Sabda Nabi s.a.w.:

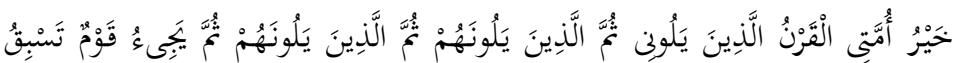

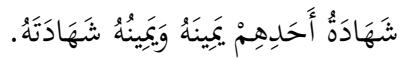

"Sebaik-baik umatku adalah kurun orang-orang selepasku, kemudian kurun orang-orang selepas mereka, kemudian kurun orang-orang selepas mereka. Kemudian datang satu kaum yang mana didahului pengakuan mereka dengan sumpah dan sumpahnya adalah pengakuannya ${ }^{, 56}$.

Bagaimana mungkin Rasulullah s.a.w. tidak hadir ketika zaman hidupnya manusia terbaik tetapi hadir di zaman ramainya pendusta yang berdusta dengan menggunakan nama Allah S.W.T yang suci. Hujah ini telah disebutkan oleh Ibn Taymiyyah ${ }^{57}$ dan alSakhāwi. ${ }^{58}$

Keempatnya, berlaku pelbagai peristiwa besar ke atas para sahabat r.a. selepas kewafatan baginda s.a.w., dan ketika itu para sahabat r.a. sangat memerlukan kehadiran Rasulullah s.a.w. di sisi mereka, namun begitu perkara tersebut tidak berlaku. Antaranya peristiwa yang berlaku adalah ${ }^{59}$ :

a. Perselisihan di kalangan Muhajirin dan Ansar berkenaan siapa yang layak menjadi khalifah umat Islam selepas kewafatan Nabi s.a.w..

b. Perselisihan di antara Abū Bakar r.a. dan Fātimah r.a. berkenaan hak warisan tinggalan harta Rasululllah s.a.w..

c. Perselisihan dahsyat antara pihak Talhah, al-Zubāir dan 'Āishah r.a dengan 'Ali bin Abī Tālib r.a. sehingga mencetuskan peperangan al-Jamal yang telah mengorbankan ramai dari kalangan para sahabat r.a. dan tabiin.

\footnotetext{
${ }^{56}$ Muslim, Saḥ̄̄h Muslim, (Riyādh: Bayt al-Afkār al-Dauliyyah, 1998), 7:184, No hadis: 6632.

${ }^{57}$ Ibn Taimiyyah, Risālah al-'Ibadāt al-Syar'iyyah wa al-Farq Bainahā wa Baina al-Bid'ah, 37.

58 Al-Qastalāni, al-Mawāhib al-Laduniyyah, 2:295.

${ }^{59}$ Muḥammad Aḥmad Lūh, Taqdīs al-Ashkhās fi al-Fikr al-Sūfi, 47.
} 
d. Pertelingkahan di antara 'Ali bin Abī Tālib r.a. dengan Mu'āwiyah r.a. sehingga mencetuskan peperangan Siffin yang menyaksikan syahidnya sebahagian besar para sahabat r.a.

e. 'Umar al-Khattāb r.a. pernah menzahirkan kesedihannya kerana beliau tidak mengetahui beberapa perkara berkaitan hukum hakam Islam dan berharap agar Rasulullah s.a.w. dapat memberikan jawapan persoalan tersebut sebelum kewafatannya. Beliau pernah berkata:

Tiga perkara aku berharap Rasulullah s.a.w. dapat menjelaskan sebelum baginda s.a.w. wafat, iaitu: bahagian harta warisan datuk, siapakah al-Kalalah serta pintu-pintu riba ${ }^{60}$.

Peristiwa-peristiwa yang berlaku ke atas para sahabat r.a. ini adalah peristiwa besar dan dahsyat. Sekiranya benar Rasulullah s.a.w. dibenarkan untuk hadir kembali ke dunia ini, seharusnya baginda s.a.w. telah hadir pada zaman sahabat r.a. untuk merelaikan perselisihan yang berlaku serta menjawab persoalanpersoalan mereka, ditambah pula mereka adalah sebaik-baik umat Islam. Perkara ini sudah tentu dapat menyelamatkan banyak nyawa serta menyelesaikan pelbagai perselisihan yang berlaku.

Kelimanya, golongan yang diiktiraf sebagai sahabat Rasulullah s.a.w. akan sentiasa wujud hingga hari kiamat. Hal ini kerana definisi sahabat r.a. adalah sesiapa yang bertemu dengan Rasulullah s.a.w. dan beriman dengan ajarannya. Maka mereka yang mendakwa melihat Rasulullah s.a.w. secara jaga adalah termasuk dalam golongan sahabat r.a. kerana mereka bertemu baginda s.a.w. secara hakikat dan mereka beriman dengan ajarannya. Hujah ini dikemukan oleh Ibn Hajar al-Asqalāni ${ }^{61}$.

Keenamnya, percanggahan keadaan Rasulullah s.a.w. hadir di sisi orang yang mendakwa melihat baginda s.a.w. secara jaga. Sebahagian mereka mengatakan Rasulullah s.a.w. hadir bersamasama jasad dan roh sebagai mana dakwaan al-Qādhi Abū Bakar al'Arabi ${ }^{62}$. Sebahagian mendakwa hanya roh sahaja yang hadir kerana adalah mustahil Rasulullah s.a.w. hadir dalam bentuk jasad,

${ }^{60}$ Al-Bukhāri, al-Jāmi' al-Ṣaḥịh, (Beirūt: Dār Tūq al-Najāh, 2002), 7:137, No hadis: 5588

${ }^{61}$ Ibn Hajar al-Asqalāni, Fath al-Bāri Sharh Sahīh al-Bukhāri, 12:385.

${ }^{62}$ Ibn Hajar al-Haithami. al-Fatāwā al-Hadithiyyah, 1:704. 
dakwaan ini diutarakan oleh Muhammad bin 'Alawi al-Māliki ${ }^{63}$ dan al-Habib 'Ali Zainal 'Ābidin al-Jufri' ${ }^{64}$. Manakala sebahagian lagi mengatakan kehadiran Rasulullah s.a.w. hanya dalam bentuk gambaran atau bayangan sahaja, dakwaan ini dipegang oleh alGhazāli ${ }^{65}$. Percangahan ini sangat meragukan kerana perkataan siapakah yang benar? Adakah roh Rasulullah s.a.w. dibenarkan keluar masuk ke dalam jasadnya pada bila-bila masa sahaja? Adakah boleh diterima bahawa Nabi s.a.w. hadir dalam bentuk roh, kemudian pada masa yang lain hadir bersama-sama jasad, pada masa yang lain hadir secara gambaran sahaja? Menurut Ibn Hajar al-Asqalāni, percanggahan ini sangat meragukan kerana alkhabar al-Sādiq (pengkhabaran yang benar) itu tidak bercanggah $^{66}$.

Ketujuhnya, hadis Abū Hurairah r.a. yang dijadikan sebagai hujah utama oleh pihak yang mendakwa keharusan melihat rasulullah s.a.w. secara jaga iaitu: "Barang siapa melihatku dalam mimpi, dia akan melihatku secara jaga" telah diriwayatkan dengan pelbagai lafaz lain tanpa perkataan "dia akan melihatku secara jaga". Selain itu, maksud lafaz hadis ini juga telah dijelaskan dengan pelbagai tafsiran yang menolak kefahamannya secara zahir. Penjelasannya seperti berikut:

a. Rangkap pertama hadis "Barangsiapa melihatku di dalam mimpi..." telah diriwayatkan oleh ramai sahabat Nabi s.a.w. antaranya Abū Hurairah, Abu Qatādah, Anas bin Mālik, Jābir bin Abdullah, Ibn Mas'ūd, Abū Sa'īd al-Khudri, Abū Juhaifah, Ibn Abbās, Tāriq bin 'Ashyam dan Abdullah bin 'Amru bin al-'Āṣ. Manakala rangkap kedua telah diriwayatkan dengan lafaz-lafaz berbeza di kalangan para sahabat r.a.. Lafaz-lafaznya seperti di jadual 1 .

\footnotetext{
${ }^{63}$ Muḥammad bin 'Alawi al-Māliki, al-Zakhāir al-Muhammadiyyah, 309-310.

${ }^{64}$ Al-Habib 'Ali Zainal Abidin al-Jufri, www.youtube.com/watch?v=VvSS3Xct _pQ, Tarikh akses: 5 Jun 2014.

${ }^{65}$ Al-Suyūti, al-Hāwi li al-Fatāwāa, 1:249.

${ }^{66}$ Ibn Ḥajar al-Asqalāni, Fatḥ al-Bāri Sharḥ Ṣaḥ̄ḥ al-Bukhāri, 12:385.
} 
Jadual 1: Perbezaan Lafaz Hadis Mengikut Riwayat Perawi

\begin{tabular}{|c|c|c|}
\hline Bil & Lafaz Rangkap Kedua & Perawi Sahabat r.a. \\
\hline 1. & $\begin{array}{l}\text { "...dia akan melihatku } \\
\text { secara jaga" }\end{array}$ & Abu Hurairah r.a ${ }^{67}$ \\
\hline 2. & $\begin{array}{l}\text { “...maka sesungguhnya } \\
\text { dia telah melihatku” }\end{array}$ & 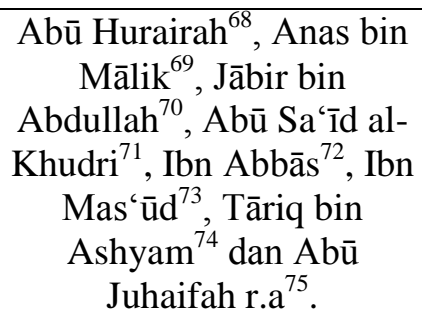 \\
\hline 3. & $\begin{array}{l}\text { "...sesungguhnya dia } \\
\text { telah melihat yang benar" }\end{array}$ & 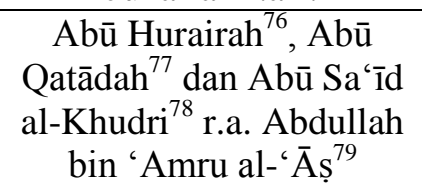 \\
\hline 4. & $\begin{array}{c}\text { "...maka seolah-olah dia } \\
\text { telah melihatku secara } \\
\text { jaga" }\end{array}$ & Abū Juhaifah ${ }^{80}$ r.a. \\
\hline 5. & $\begin{array}{c}\text { “...dia akan melihatku } \\
\text { secara jaga atau seolah- } \\
\text { olah dia telah melihatku } \\
\text { secara jaga- perawi ragu- } \\
\text { ragu" }\end{array}$ & Abū Hurairah ${ }^{81}$ r.a. \\
\hline
\end{tabular}

67 Al-Bukhāri, al-Jāmi' al-Șaḥịh, 9:42, No hadis: 6993.

${ }^{68}$ Al-Bukhāri, al-Jāmi' al-Șaḥ̄ḥ, 1:38, No hadis: 110.

${ }^{69}$ Al-Bukhāri, al-Jāmi' al-Ṣaḥ̄h, 9:42, No hadis: 6994.

${ }^{70}$ Muslim, Sahīh Muslim, 7:54, No hadis: 6060.

${ }^{71}$ Ibn Mājah, Sunan Ibn Mājah, (Beirūt: Dār al-Jail, 1998), 5:61, No hadis: 3903.

${ }^{72}$ Ibn Mājah, Sunan Ibn Mājah, 5:61, No hadis: 3905.

73 Al-Tirmidhi, Sunan al-Tirmidhi, (Riyādh: Maktbah al-Ma'ārif Li al-Nashar wa al-Tauzi', 1997), 4:535, No hadis: 2276.

74 Ahmad bin Hanbal, Musnad Ahmad bin Hanbal, 3:472, No hadis: 15921.

75 Al-Bazzār, Musnad al-Bazzār, (Al-Madīnah al-Munawwarah: Maktabah al'Ulūm wa al-Hikam, 2009), 10:160, No hadis: 4233.

${ }^{76}$ Ahmad bin Hanbal, Musnad Ahmad bin Hanbal, 2:261, No hadis: 7544.

77 Al-Bukhāri, al-Jāmi' al-Șaḥịh, 9:42, No hadis: 6996.

78 Al-Bukhāri, al-Jāmi' al-Șaḥ̆ḥ, 9:43, No hadis: 6997.

79 Al-Tabrāni, Musnad al-Syāmiyìn, (Beirūt: Muassasah al-Risālah, 1984), 3:397, No hadis: 2542.

${ }^{80}$ Ibn Mājah, Sunan Ibn Mājah, 5:61, No hadis: 3904.

${ }^{81}$ Ahmad bin Hanbal, Musnad Ahmad bin Hanbal, 5:306, No hadis: 22659. 
Berdasarkan lafaz-lafaz ini, diketahui bahawa sambungan kedua rangkap hadis mimpi melihat Nabi s.a.w. telah diriwayatkan dengan lima lafaz berbeza. Lafaz hadis "...dia akan melihatku secara jaga" hanya diriwayatkan daripada Abū Hurairah r.a. sahaja, bahkan hadis daripada Abu Hurairah turut diriwayatkan dengan tiga lafaz yang lain di mana dua daripadanya telah diriwayatkan oleh al-Bukhāri dalam kitab sahihnya.

b. Para ulama hadis antaranya Ibn Hajar al-Asqalāni ${ }^{82}$, Ibn Battul $^{83}$, Badr al-Dīn al-'Aini' ${ }^{84}$ dan Aḥmad "Umar Hāshim ${ }^{85}$ menjelaskan maksud hadis "...dia akan melihatku secara jaga" seperti berikut:

i. Ia merupakan tashbīh (perumpamaan) sebagai tanda bahawa mimpi tersebut adalah mimpi yang benar kerana syaitan tidak dapat menyerupai Rasulullah s.a.w. walaupun di dalam mimpi.

ii. Konteks hadis tersebut hanyalah ditujukan pada zaman Rasulullah s.a.w. sahaja. Ia bermaksud barang siapa yang hidup ketika zaman baginda s.a.w. dan beriman dengan kerasulannya, namun belum berhijrah daripada Mekah ke Madinah untuk bertemu dengan baginda s.a.w., maka mimpi tersebut merupakan khabar gembira bahawa Allah s.w.t akan memberinya taufik untuk berhijrah dan bertemu dengan Rasulullah s.a.w. sebelum dia meninggal dunia.

iii. Ia merupakan khabar gembira bahawa orang yang bermimpi itu akan melihat Rasulullah s.a.w. di akhirat secara jaga.

iv. Ia merupakan khabar gembira kepada orang yang bermimpi bahawa di akhirat nanti dia akan melihat Rasulullah s.a.w. secara jaga dalam keadaan persendirian yang khusus serta turut menggambarkan penghampiran kedudukannya dengan Rasulullah s.a.w. untuk mendapat syafaatnya.

${ }^{82}$ Ibn Hajar al-Asqalāni, Fath al-Bāri Sharh Șaḥịh al-Bukhāri, 12:385.

${ }^{83}$ Ibn Battul, Sharh Saḥ̄ḥ al-Bukhāri, (Riyādh: Maktabah al-Rushd, 2003), 9:527.

${ }^{84}$ Badr al-Dīn al-'Aini, Umdah al-Qāri Sharh Ṣaḥ̄h al-Bukhāri, (Beirūt: Dār alKutub al-'Ilmiyyah, 2001), 3:284.

${ }^{85}$ Ahmad 'Umar Hāshim, al-Islām wa al- Imān wa al-'Ilm, (al-Qāhirah: al-Dār al-Misriyyah al-Sa'ūdiyyah, t.thn), 120. 


\section{Perbincangan dan Tarjih}

Asal hukum melihat secara jaga seseorang yang telah meninggal dunia adalah tidak harus berlaku. Oleh itu, dakwaan melihat Rasulullah s.a.w. secara jaga selepas kewafatannya memerlukan dalil yang kukuh bagi mensabitkan kebenaran dan keharusannya. Berdasarkan analisis pandangan serta dalil yang dikemukan oleh pihak yang mendakwa serta pihak yang menolak dakwaan ini, disimpulkan bahawa melihat Rasulullah s.a.w. secara jaga merupakan perkara ghaibiyyāt yang tidak dapat dibuktikan secara jelas dan kukuh akan kebenarannya. Tambahan pula wujud beberapa keraguan dalam dakwaan ini seperti berikut:

1. Dakwaan melihat Rasulullah s.a.w. secara jaga dikenal pasti bermula pada kurun ke tiga Hijrah. Sebelum zaman tersebut iaitu zaman sahabat r.a, tabiin dan tabi'in dakwaan ini tidak pernah kedengaran.

2. Kisah-kisah yang menceritakan perihal melihat Rasulullah s.a.w. secara jaga tidak dapat dipastikan kesahihannya sama ada melalui bukti atau saksi pihak kedua kerana ia hanya diceritakan oleh sebahagian orang tertentu sahaja yang mendakwa mengalami peristiwa tersebut.

3. Pihak yang mendakwa keharusan melihat Rasululllah s.a.w. secara jaga berselisihan tentang kaedah melihat, sama ada penglihatan tersebut dengan mata zahir atau mata hati atau pandangan dalam keadaan barzakh, atau perasaan jiwa. Sesungguhnya pengkhabaran yang benar itu tidak bercanggahan.

4. Pihak yang mendakwa juga berselisihan berkenaan keadaan kehadiran Rasulullah s.a.w., sama ada kehadiran tersebut dengan roh dan jasad baginda s.a.w. atau roh sahaja atau gambaran/bayangan sahaja.

Dalil-dalil yang dipegang oleh pihak yang mendakwa juga tidak kukuh dan tidak memadai untuk mensabitkan sesuatu perkara tidak seharusnya berlaku. Huraiannya adalah seperti berikut:

1. Dalil utama yang dipegang oleh pihak yang mendakwa iaitu "Barang siapa melihatku di dalam mimpi maka dia akan melihatku secara jaga" adalah lafaz riwayat ahăd kerana ia hanya diriwayatkan daripada Abū Hurairah r.a. sahaja, manakala lafaz riwayat mashür daripada ramai sahabat yang lain tidak 
menyebutnya. Oleh itu, lafaz riwayat mashūr perlu didahulukan daripada riwayat $a h \bar{a} d$.

2. Dalil hadis daripada Abū Hurairah r.a. di atas telah dihuraikan oleh ramai ahli hadis dengan pelbagai penjelasan yang menolak pemahaman lafaz hadis secara zahir.

3. Dalil bahawa Nabi Muhammad s.a.w. dan seluruh para Nabi a.s. adalah hidup disandarkan kepada peristiwa Rasulullah s.a.w. melihat dan bertemu dengan para Nabi a.s. sebelumnya, serta bersandarkan kepada hadis sahih bahawa para Nabi a.s. hidup dan mereka bersolat di dalam kubur mereka. Maka setiap perkara luar biasa yang harus berlaku ke atas Nabi s.a.w., harus juga berlaku kepada para wali tetapi tanpa al-tahaddi. Hujah ini menzahirkan dua kemungkinan iaitu sama ada mereka terlalu memuliakan wali sehingga meletakkannya setaraf kurang satu darjat dari Nabi s.a.w. atau mereka merendahkan Nabi s.a.w. sehingga menyamakan baginda s.a.w. hampir dengan mertabat dan kedudukan wali. Rasulullah s.a.w. adalah manusia pilihan Allah S.W.T. dan dikurniakan dengan pelbagai perkara luar biasa yang berbentuk al-țahaddi (cabaran) dan tidak berbentuk al-țahaddi. Perkara luar biasa berbentuk al-tahaddi yang berlaku kepada Rasulullah s.a.w. hanyalah penurunan al-Quran seperti mana firman Allah S.W.T.:

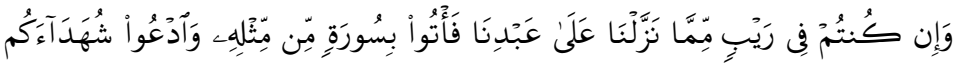

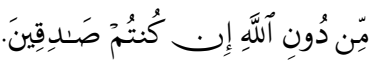

"Dan sekiranya kamu ragu-ragu dengan apa yang telah kami turunkan kepada hamba kami, maka datangkanlah satu surah seumpamanya dan serulah pembantu-pembantumu selain Allah jika kamu di kalangan orang yang benar."

Al-Baqarah: 2:23

Mukjizat selain al-Quran adalah tidak berbentuk al-țahaddi seperti peristiwa membelah bulan, berjumpa dan berkata-kata dengan para malaikat, dibawa naik ke sidrah al-Muntaha untuk bertemu dengan Allah S.W.T., mengetahui perkara-perkara ghaibiyyāt tentang syurga dan nerara serta perkara-perkara yang akan berlaku di masa hadapan dan lain-lain lagi. Maka bagaimanakah mereka boleh meletakkan keistimewaan wali-wali setaraf dengan Rasulullah s.a.w.? Sesungguhnya jika terdapat manusia yang sejengkal menyamai martabat Rasulullah s.a.w., 
nescaya mereka adalah para sahabat baginda s.a.w.. Sabda Rasulullah s.a.w.:

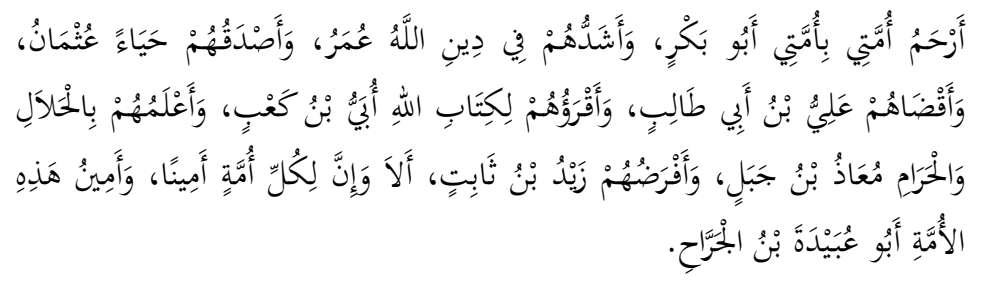

"Sekasih-kasih manusia di kalangan umatku kepada umatku adalah Abū Bakar, setegas-tegas di kalangan mereka terhadap perintah Allah adalah 'Umar, sebenar-benar malu di kalangan mereka adalah 'Uthman, yang paling mengetahui halal dan haram di kalangan mereka adalah $M u ' \bar{a} z$ bin Jabal, yang paling mengetahui berkaitan pembahagian harta pusaka di antara mereka adalah Zaid bin Thābit, yang paling elok bacaannya di kalangan mereka adalah Ubai, dan bagi setiap umat itu ada seorang yang dipercayai, orang yang dipercayai di kalangan umat ini adalah Abū 'Ubaidah al-Jarrāh ${ }^{86 ", .}$

Oleh kerana hujah serta dalil yang dikemukan oleh pihak yang mendakwa tidak kukuh serta mengandungi banyak keraguan, maka dakwaan melihat Rasulullah s.a.w. secara jaga adalah tertolak. Justeru, tidak perlulah dibincangkan hujah serta dalil yang dikemukan oleh pihak yang menolak dakwaan ini.

\section{Penutup}

Berdasarkan analisis pandangan, hujah dan dalil pihak yang mendakwa keharusan melihat Rasulullah s.a.w. serta pihak yang menolak dakwaan tersebut, dirumuskan bahawa melihat Rasulullah s.a.w. secara jaga di dunia ini selepas kewafatannya adalah dakwaan yang tidak boleh diterima kesahihannya. Dakwaan ini juga menyalahi al-Quran dan al-Sunnah serta menyimpang dari pegangan ahli Sunnah Wal Jamaah sama ada secara 'aqli dan naqli. Dakwaan bertemu Rasulullah s.a.w. secara yaqazah tidak boleh diterima secara 'aqli kerana dakwaan ini hanya mula wujud pada zaman ketiga Hijrah dan tidak wujud pada

\footnotetext{
${ }^{86}$ Al-Tirmidhi, Sunan al-Tirmidhi, 664:5, No hadis: 3790.
} 
zaman sahabat atau zaman tabi' atau zaman tabi'in, ketiadaan bukti kukuh atau saksi yang layak bagi mengesahkan kesahihan dakwaan, kewujudan percanggahan keadaan penglihatan ketika melihat kehadiran Rasulullah s.a.w. secara jaga serta percanggahan mengenai keadaan diri Rasulullah s.a.w. ketika baginda hadir. Selain itu dakwaan ini juga tidak boleh diterima secara naqli kerana riwayat-riwayat mashür menolak penafsiran secara zahir lafaz hadis "Barang siapa melihatku di dalam mimpi maka dia akan melihatku secara jaga". Manakala dalil hadis bahawa Rasulullah s.a.w. pernah melihat para nabi a.s. sebelumnya secara jaga turut tidak boleh diterima untuk mengharuskan melihat Rasulullah s.a.w. secara jaga selepas kewafatannya kerana baginda s.a.w. adalah manusia terpilih yang dikurniakan pelbagai mukjizat berbentuk al-țhaddi dan tidak altahaddi, maka tidak boleh disamakan hal keadaan baginda s.a.w. dengan manusia yang lain.

\section{Bibliografi}

Abd al-Ḥaȳ Abd al-Halīm al-Laknawi, al-Athār al-Marfū 'ah fì alAkhbār al-Maudhū'ah. (Beirūt: Dār al-Kutub al-'Ilmiyyah, t.thn).

Abd al-Muhsin al-'Ibād, Sharh Sunan Abī Dāūd, Islamweb.net

(Kaset Rakaman) http://audio.islamweb.net/audio/index.php ?page $=$ lecview \&sid $=317 \&$ read $=0 \& l g=338$.

Abd al-Raḥmān bin Ab̄i al-Hasan al-Jauzi, al-Qașaș wa alMudhakkirīn, (Beirūt: al-Maktabah al-Islāmi, 1988).

Abu Abdullah Muhammad bin Abd al-Bāqi al-Zurqāni, Sharh al'Alāmah al-Zurqāni 'Alā al-Mawāhib al-Laduniyyah, (Beirūt: Dār al-Kutub al-'Ilmiyyah, 1996).

Abū Abdullāh Shams al-Dīn Muḥammad bin Aḥmad al-Dhahabi, Mìzan al-'Itidāl fi Naqd al-Rijāl, (Beirūt: Dār al-Kutub al'Ilmiyyah, 1995).

al-Risālah, 1985).

Siar A'alām al-Nubalā'. (Beirūt: Muassasah

Abū al-Abbās Aḥmad bin 'Umar al-Ansāri al-Qurtubi, alMufahhim Limā Ushkila min Talkhīs Kitāb Muslim, (Beirūt: Dār Ibn Kathīr, 1996). 
Abu al-Fidā' 'Imād al-Dīn Ismā'īl bin 'Umar bin Kathīr, alBidāyah wa al-Nihāyah, (Beirūt: Dār Iḥyā' al-Turāth al-'Arabi, 1988).

Abū al-Mawāhib Abd al-Wahhāb bin Aḥmad al-Sya'rāni, alTabaqāt al-Ṣughra@Lawāqih al-Anwār fi Bayān al-'Uhūd alMuhammadiyyah, (Halab: Dār al-Qalam al-'Arabi, 1993). , al-Tabaqāt al-Kubrā@Lawāqih al-Anwār fì al-Tabaqāt al-Akhyār, (Beirūt: Dār al-Kutub al-'Ilmiyyah, 1997).

Abū Dāūd, Sunan Abī Dāūd, (Riyādh: Maktabah al-Ma'ārif li alNashar wa al-Tauzi', 2003).

Aḥmad 'Umar Hāshim, al-Islām wa al- Imān wa al-'Ilm, (alQāhirah: al-Dār al-Misriyyah al-Sa'ūdiyyah, t.thn).

Aḥmad bin Hanbal, Musnad Aḥmad bin Hanbal. (Beirūt: Muassasah al-Risālah, 2001).

Al-Albāni, Muḥammad Nāsir al-Dīn, Șahịh wa Dha 'ịf al-Jāmi' alȘaghīr wa Ziyādatuh, (Dimasyq: Maktabah al-Islāmi, 1988).

Al-Bazzār, Musnad al-Bazzār, (Al-Madīnah al-Munawwarah: Maktabah al-'Ulūm wa al-Hikam, 2009).

Al-Bukhāri, al-Jāmi' al-Sậ̄ịh, (Beirūt: Dār Tūq al-Najāh, 2002).

Al-Tabrāni, Musnad al-Syāmiyīn, (Beirūt: Muassasah al-Risālah, 1984).

Al-Tirmidhi, Sunan al-Tirmidhi, (Riyādh: Maktbah al-Ma'ārif Li al-Nashar wa al-Tauzi', 1997).

Badr al-Dīn al-'Aini, Umdah al-Qāri Sharh Sah̄̄h al-Bukhāri, (Beirūt: Dār al-Kutub al-'Ilmiyyah, 2001).

Ibn Battul, Sharh Saḥịh al-Bukhāri, (Riyādh: Maktabah al-Rushd, 2003).

Ibn Mājah, Sunan Ibn Mājah, (Beirūt: Dār al-Jail, 1998).

Ibn Taimiyyah Taqiyuddīn Aḥmad bin Abd al-Halīm, Risālah al'Ibadāt al-Syar'iyyah wa al-Farq Bainahā wa Baina al-Bid' $a h$. (Al-Ihsā': Maktabah Ibn al-Jauziyyah, t.thn).

Ismā'īl bin Muḥammad al-Jarāḥi al-'Ajlūni, Kash al-Khafā' wa Muzīl al-Ilbās 'Ammā Ishtahara min al-Aḥādith 'alā Alsinah alNās. (Beirūt: Dār Ihyā' al-Turath, 2000).

Jalāl al-Din Abd al-Raḥmān bin al-Kamāl al-Suyūti, al-Dībāj 'Alā Saḥịh Muslim, (Saudi Arabia: Dār Ibn Affān, 1996),

al-Qurāniyyah, 2000). al-Hāwi li al-Fatāwā, (Beirūt: Dār al-Kutub 
Jalāl al-Dīn Abd al-Raḥmān bin al-Kamāl al-Suyūti, Nuzūl 'is̄a bin Maryam fì Ākhir al-Zamān, (Iskandariah: Dār Ibn Khaldūn, t.thn).

Muhammad Abd al-Raūf bin Tāj al-'Ārifīn al-Manāwi, Faydh alQadīr Sharh al-Jāmi' al-Ṣaghīr, (Beirūt: Dār al-Kutub al'Ilmiyyah, 1994).

Muḥammad Aḥmad Lūh, Taqdīs al-Ashkhās fi al-Fikr al-Sūfi, (AlQāherah: Dār Ibn 'Affān, 2002).

Muhammad al-Nūr bin Dhaiffullāh, Tabaqāt Wad Dhaifullāh, (Beirūt: Markaz al-Saff al-Ilektrōni, 2000).

Muhammad bin 'Alawi al-Māliki, al-Zakhāir al-Muḥammadiyyah, (Al-Qāherah: Dār al-Jawāmi’ al-Kalām, 1995).

Muhammad bin Ismā‘̄̄l al-San‘āni, al-Insā̄f fi Haqūqoh al-Auliyā' wamā Lahum min al-Karōmāt wa al-Altōf. (Al-Qāherah: Dār Ibn Affān, 1997).

Muslim, Șaḥīh Muslim, (Riyādh: Bayt al-Afkār al-Dauliyyah, 1998).

Shihāb al-Dīn Abū al-Abbās Aḥmad bin Muḥammad al-Haithami, al-Fatāwā al-Hadīthiyyah, (Beirūt: Dār al-Fikr, t.thn).

Shihāb al-Dīn Aḥmad bin 'Ali al-Asqalāni, al-Is̄abah fi Tamyīz alSahābah, (Beirūt: Dār al-Jail, 1991).

, Fath al-bāri Sharh Sahīh al-Bukhāri. (Beirūt:

Dār al-Ma'rifah, 1960).

Shihāb al-Dīn Aḥmad bin Muhammad al-Qastolāni, al-Mawāhib al-Laduniyyah, (Dimasyq: al-Maktab al-Islāmi, 2004).

http://www.youtube.com/watch?v=9SfTX-TCu8Y. Tarikh Akses: 2 Julai 2014.

http://www.youtube.com/watch?v=4mo8nw-skPE. Tarikh akses: 2 Julai 2014.

http://www.youtube.com/watch?v=qor8Z1QgfKY. Tarikh akses: 2 Julai 2014.

http://www.youtube.com/watch? $\mathrm{v}=\mathrm{mGxy} 68 \mathrm{rfp} 6 \mathrm{E}$. Tarikh akses: 5 Jun 2014.

http://youtube.com/watch?v=VvSS3Xct_pQ. Tarikh akses: 5 Jun 2014.

http://www.youtube.com/watch?v=rg610HvsQUs. Tarikh akses: 5 Jun 2014. 
Amir dan Aminuddin, Dakwaan Melihat dan Bertemu Rasulullah SAW 